\title{
Production and Quantification of Virulence Factors in Malassezia Species
}

Inès Hadrich ( $\square$ ineshadrich@yahoo.fr)

Laboratoire de biologie moléculaire parasitaire et fongique

Sourour Neji

Université de Sfax Faculté de Médecine de Sfax: Universite de Sfax Faculte de Medecine de Sfax

Houaida Trablesi

Université de Sfax Faculté de Médecine de Sfax: Universite de Sfax Faculte de Medecine de Sfax

Amin llahi

Université de Sfax Faculté de Médecine de Sfax: Universite de Sfax Faculte de Medecine de Sfax

Taieb Chouaki

CHU Amiens-Picardie: Centre Hospitalier Universitaire Amiens-Picardie

Stéphane Ranque

Hospital Timone: Hopital de la Timone

Fattouma Makni

Université de Sfax Faculté de Médecine de Sfax: Universite de Sfax Faculte de Medecine de Sfax

Ali Ayadi

Université de Sfax Faculté de Médecine de Sfax: Universite de Sfax Faculte de Medecine de Sfax

\section{Research Article}

Keywords: Malassezia, real time qRT-PCR, virulence factors, extracellular hydrolases, biofilm

Posted Date: December 9th, 2021

DOI: https://doi.org/10.21203/rs.3.rs-1030849/v1

License: (c) (1) This work is licensed under a Creative Commons Attribution 4.0 International License. Read Full License 


\section{Abstract}

A total of 77 strains of Malassezia were included in this study. Biofilm production and hydrolytic enzymes were studied by using specific solid media. Realtime Reverse Transcriptase qPCR method was applied to determine overexpression of genes encoding extracellular enzyme. All included Malassezia species produced biofilms. No statistical significant difference was observed between biofilm formation of the Malassezia species $(P=0.567)$. All Malassezia species produced lipase and $95 \%$ of $\mathrm{M}$. globosa showed a strong enzymatic activity ( $\mathrm{Pz}=0.55 \pm 0.02$ ). Statistical significant difference was observed between the mean keratinase indices of $\mathrm{M}$. slooffiae and the others Malassezia species $(P=0.005)$. The overexpression of one or more genes was observed in $100 \%$ of strains isolated from patients with folliculitis, in $87.5 \%$ for pityriasis versicolor isolates and in $57.14 \%$ for the control group isolates. A statistical significant difference of the lipase gene expression $(P=0.072)$ was associated with the strains collected from patients with folliculitis vs group control. This investigation provides more information about the frequency of the production of the major enzymes considered to be virulence factors of Malassezia species. Interestingly, the overexpression of one or more genes was observed in strains isolated from patients with Malassezia disorder.

\section{Introduction}

Malassezia species, which are members of the human healthy skin, may cause a wide range of cutaneous and systemic diseases in predisposed individuals. Thus, they exist at the interface between commensal and pathogen. Their interaction with the human immune system is of great interest, despite being members of the indigenous cutaneous microbial population [1].

When the physical, chemical or immunological mechanisms of the skin are altered, this yeast can become pathogenic [2-6]. Classic skin diseases caused by Malassezia yeasts include pityriasis versicolor (PV), seborrheic dermatitis and Malassezia folliculitis.

Particular features of Malassezia organisms such as its non autoaggregation behavior and a very high lipolytic enzyme activity may play an important role in the pathogenicity of parenteral lipid emulsion Malassezia-related species [7].

Recently, the role of Malassezia lipases and phospholipases as pathogenicity mechanisms in seborrheic dermatitis was enhanced by the demonstration of significant increased expression of lipase genes [8]. This finding was also supported by the in vitro induction of phospholipase activity of Malassezia seborrheic dermatitis isolates by $\beta$-endorphin, another putative virulence factor increased in inflammatory skin conditions [9].

Among keratinophilic microorganisms, Malassezia for which the ability of digesting keratin constitutes a condition of their growth and development plays an important role.

A further health threat by these pathogens is their propensity to develop biofilm on skin and at the surface of indwelling medical devices. Biofilm represents a serious medical problem because it promotes resistance to antifungal drugs and acts as a reservoir for the seeding of infectious organisms at distant places [10]. Real-time PCR has become one of the most widely used methods of gene quantitation because it has a large dynamic range, boasts tremendous sensitivity, can be highly sequence-specific. The advent of real-time PCR and real-time reverse transcription PCR (real-time RT-PCR) has dramatically changed the field of measuring gene expression. Real-time PCR is the technique of collecting data throughout the PCR process as it occurs, thus combining amplification and detection into a single step. This is achieved using a variety of different fluorescent chemistries that correlate PCR product concentration to fluorescence intensity.

The aim of the present study was to quantify biofilm production and to investigate the extracellular production of lipase, phospholipase and keratinase for 6 Malassezia species by using microbiological and Real-time Reverse Transcriptase qPCR methods. In addition, we examined whether virulence factors inherent in the organisms themselves might predict clinical significance.

\section{Materials And Methods}

\section{Isolates}

A total of 77 strains of Malassezia were included in the study: 20 M. globosa, 10 M. restricta, 14 M. furfur, 7 M. sympodialis, 5 M. slooffiae and 21 M. pachydermatis. They were collected from patients with Malassezia folicullitis (12), from babies of neonatal intensive care unit (20), pityriasis versicolor (10) and control groups (35). These strains were identified by real time qPCR using a specific hydrolysis probe as previously described [11].

\section{Evaluation of biofilm formation by crystal violet staining (CVS)}

Biofilm formation of Malassezia species using crystal violet staining (CVS) was performed as reported previously with some modifications [12]. The strains were cultured on Dixon agar at $32{ }^{\circ} \mathrm{C}$ for 3 days. Thus, the culture was suspended in Dixon Liquid. The suspension (150 $\mu$ l) adjusted to match turbidity comparable to that of the $0.5 \mathrm{McF}$ arland standard $\left(10^{6} \mathrm{CFU} / \mathrm{ml}\right)$ and $200 \mu \mathrm{L}$ of Dixon Liquid were placed into selected wells of $96-$ well polystyrene microtiter plates (Kartell. SPA, Italy). The plate was then incubated at $32{ }^{\circ} \mathrm{C}$ on a shaker at $120 \mathrm{rpm} / \mathrm{min}$. At $24 \mathrm{~h}, 200 \mu \mathrm{L}$ of sterile Dixon Liquid was added and incubated $48 \mathrm{~h}$ under the same conditions. Subsequently the medium was removed and each well was washed with sterile ultra-pure water.

For fixation of the biofilm, $200 \mu$ of absolute methanol $(15 \mathrm{~min})$ were added and removed. The polystyrene microtiter plates are kept at room temperature for drying and $200 \mu$ of crystal violet of CV $(1 \% \mathrm{v} / \mathrm{v})$ added to each well and incubated for $5 \mathrm{~min}$. Then, multiple washing with ultra-pure water was done until complete elimination (CV) and finally $200 \mu \mathrm{l}$ of acetic acid were added.

A microtiter plate reader (Bio-Tek Synergy HT, Izasa, Lisbon, Portugal) at $620 \mathrm{~nm}$ was used for reading the absorbance in each well.

Page 2/11 


\section{Evaluation of phospholipase production}

The production of phospholipase was assessed using the egg-yolk plate method. Briefly, the isolates were incubated in Dixon agar. Thus, the culture was suspended in Dixon Liquid. Ten microliters of yeast suspension prepared from a fresh culture $\left(10^{6} \mathrm{cells} / \mathrm{ml}\right.$ determined through densitometer) was spot inoculated in triplicate onto the medium and incubated at $32{ }^{\circ} \mathrm{C}$ for 10 days. The formation of precipitation zones surrounding the colonies was considered as an indicator for enzyme production. The diameter of the colony $(a)$ and the diameter of the precipitation zone plus the diameter of the colony $(b)$ were measured. Phospholipase index was designated as $\mathrm{Pz}=a / b$, as described by Coutinho and Paula [13, 14]. According to this definition, low Pz values mean high enzymatic production and, inversely, high Pz values indicate low enzymatic production. The enzymatic activity was scored into four categories: a Pz of 1.0 indicated no enzymatic activity (nul); a Pz between 0.99 and 0.90 indicated weak enzymatic activity; Pz between 0.89 and 0.70 corresponded to high activity; and low Pz values $\leq 0.69$ mean very high enzymatic activities.

\section{Evaluation of lipase production}

The strains were inoculated in triplicate on agar plates containing Tween 80 as substrate (bactopepton $10 \mathrm{~g}$; sodium chloride $5 \mathrm{~g}$; calcium chloride $0.1 \mathrm{~g}$; agar $20 \mathrm{~g}$; Tween $8020 \% 50 \mathrm{~mL}$; water $950 \mathrm{~mL}$ ) and incubated for 7 days at $32^{\circ} \mathrm{C}$. Precipitation halo and colony size were measured.

Degradation intensity was gauged by the ratio between colony diameter and precipitation halo (Pz). Pz coefficients were grouped into five classes: very low group: Pz between 0.9 and 1, low group: Pz between $0.89-0.8$, high group: Pz between $0.79-0.70$; and very high group: $P z$ less than 0.69 or null $(P z=1)$.

\section{Evaluation of keratinase production}

The preparation of keratin substrate (KS) was extracted from white chicken feathers. Ten g of feathers was heated in $200 \mathrm{ml}$ of DMSO (Dimethylsulfoxide) for 2 hours at $100{ }^{\circ} \mathrm{C}$. Solution was precipitated for soluble keratin by using 2 volume of cold acetone for 1 volume of protein. Then, caseous precipitate of keratin protein was suspended in $0.1 \mathrm{M}$ of phosphate buffer. Afterwards, soluble keratin protein was added in the solid medium at a concentration of $0.06 \%$. Solid medium was inoculated with micropipette, injecting $10 \mu \mathrm{l}$ of standard suspension into center of the petri plate and incubated at $32{ }^{\circ} \mathrm{C}$. Control plates were containing medium without keratin substrate. Formation of precipitate zones around the colonies indicated keratinase enzyme production and zone was examined and measured. Pz coefficients were grouped into five classes as it was described for lipase activity.

\section{Virulence gene expression}

A RT-qPCR assay was newly developed to explore virulence gene expression of $20 \mathrm{M}$. globosa isolates. The levels of mRNA and DNA copies of the tested genes (Keratinase, Lipase, and Phospholipase) and the actin reference gene (ACT1) were measured.

The primers and probes were designed using Primer3 software (http://bioinfo.ut.ee/primer3-0.4.0/), verified by using sequence manipulation suite software (http://bioinformatics.org/sms2/) and were summarized in Table 1.

Cellular lysates were prepared from cells grown in culture in Dixon medium (reference) and lipase, keratinase and phospholipase medium to mid-log phase using proteinase K (Qiagen $®)$.

RNA was extracted from cellular lysates using the RNeasy Mini Kit (Qiagen ${ }^{\circledR}$, Germany) according to the manufacturer s' instructions, and treated with DNase (Promega).

For cDNA synthesis, $2.5 \mu$ l of total RNA was used as a template and subsequent reverse transcription was performed using the PrimeScript RT Reagent Kit (Perfect Real Time) from TaKaRa (Shiga, Japan), following the manufacturer's instructions.

The reaction mixture $(20 \mu \mathrm{l})$ for TaqMan assay contained $10 \mu \mathrm{l}$ TaqMan Universal PCR Master Mix (Applied Biosystems, UK), 20 pmol of forward and reverse primers, $7 \mathrm{pmol}$ of hydrolysis probe and $1 \mu \mathrm{l}$ of of template (extracted DNA or cDNA). The thermal conditions were as follows: initial holding stage at $50{ }^{\circ} \mathrm{C}$ for $2 \mathrm{~min}$ and $95^{\circ} \mathrm{C}$ for $10 \mathrm{~min}$, followed by 50 cycles at $95^{\circ} \mathrm{C}$ for $15 \mathrm{~s}$ and a final step at $54^{\circ} \mathrm{C}$ for $1 \mathrm{~min}$. All reactions were performed in triplicate in 48 -well reaction plates using a CFX 96 Real-Time System (BioRad).

Fold changes in target gene expression were then normalized to reference gene via the published comparative $2-\Delta \Delta \mathrm{Cq}$ method according to the formula: $\mathrm{RQ}$ $=2-($ Cq target - Cq reference) tested $-($ Cq target - Cq reference) control. Reference control was the isolate (TN371, KU597270) cultured in Dixon medium. A change of 2.5 times was considered as gene overexpression or an increase in gene copy number.

\section{Statistical analysis}

Statistical analyses were performed using IBM SPSS software (version 20.0; IBM SPSS Inc., New York,USA).

\section{Results}

\section{Biofilm Formation}

The formation of biofilm was positive for all Malassezia species (Figure 1). The amount of biofilm formed in each case was estimated in triplicate and an average was calculated for each isolate (Figure1). The amounts of obtained biofilms were (Abs moy $=0.322 \pm 0.01)$ for $M$. globosa, $($ Abs moy $=0.336 \pm 0.01$ ) for M. furfur. (Abs moy $=0.336 \pm 0.02$ ) for M. restricta, (Abs moy $=0.349 \pm 0.02$ ) for M. pachydermatis, (Abs moy $=0.256 \pm 0.0 .02)$ for M. slooffiae and (Abs moy $=0.235 \pm 0.02$ ) for M. sympodialis (Table 2). 
No statistical significant difference was observed between biofilm formation of the Malassezia species $(P=0.567)$. Strains collected from neonates had the highest biofilm production (Abs moy $0.396 \pm 0.02$ ) followed by strains from folliculitis (Abs moy $0.342 \pm 0.01$ ) and pityriasis versicolor (Abs moy $0.313 \pm$ 0.02). Strains isolated from control group had the lowest amounts of obtained biofilms (Abs moy $0.291 \pm 0.02$ ) (Table 2). However, there was no statistically significant association between biofilm-forming ability and the clinical origin of the isolates $(P=0.570)$.

\section{Lipase activity}

The lipase activity was positive for all Malassezia species. A total of 19 isolates of $M$. globosa $(95 \%)(P z=0.55 \pm 0.02)$ and 5 isolates of $M$. sympodialis $(71.43 \%)(P z=0.54 \pm 0.02)$ showed a very high enzymatic activity (Table 3$)$.

Strains isolated from pityriasis versicolor showed a very high activity with Pz values between $(0.36 \pm 0.02,0,28 \pm 0.01)$ (Table 4). But, no statistical significant difference was observed between the mean lipase indices and the clinical origin of the isolates $(P=0.356)$.

\section{Phospholipase activity:}

All isolates of M. furfur, M. globosa, M. sympodialis, M. slooffiae and M. pachydermatis included in this study demonstrated a high or a very high phospholipase activity (Figure 2). But, only $70 \%$ of the $M$. restricta isolates showed a high activity (Table 3 ). A high level of the activity with a Pz values $(0.66 \pm 0.02)$ was found in $95 \%$ of neonates samples (Table 4$)$.

But, no statistical significant difference was observed between the mean phospholipase production and the clinical origin of isolates $(\mathrm{P}=0.65)$.

\section{Keratinase activity}

The Pz values for keratinase activity of Malassezia isolates ranged from 0.33 to 0.91 . All M. slooffiae strains showed a positive keratinase activity (Figure 2 ) and $40 \%$ were shown to be very high producers (Table 3 ).

A total of 16 isolates of $M$. globosa (80\%) $(\mathrm{Pz}=0.65 \pm 0.02), 4$ isolates of $M$. sympodialis $(57.15 \%)(\mathrm{Pz}=0.62 \pm 0.03), 7$ isolates of $M$. furfur $(50 \%)(\mathrm{Pz}=0.67 \pm$ $0.02), 2$ isolates of $M$. restricta $(20 \%)(P z=0.69 \pm 0.02)$ and 11 isolates $M$. pachydermatis $(52.29 \%)(P z=0.68 \pm 0.02)$ showed a keratinase activity $($ Table 3$)$.

Statistical significant difference was observed between the mean keratinase indices of $M$. slooffiae and the others Malassezia species $(\mathrm{P}=0.005)$.

Correlation analysis results with Pearson's coefficient revealed a positive correlation between secretion of keratinase and phospholipase $(r=0.31$, $P<0.001)$.

\section{Expression of keratinase, Lipases and Phospholipases of M. globosa}

We analyzed by RT-qPCR the quantitative expression and copy number of 3 genes (keratinase, lipase and phospholipase) responsible for the virulence of 20 M. globosa strains collected from patients with folliculitis (5), patients with pityriasis versicolor (8) and control group (7), comparing to the ACT1 gene and the isolate (TN371, KU597270) cultured in Dixon meduim. The overexpression of one or more genes was observed in $5 / 5$ (100\%) of strains isolated from patients with folliculitis in $7 / 8$ (87.5\%) for pityriasis versicolor isolates and in $3 / 7$ (57.14\%) for control group isolates (Table 5). The level of expression of keratinase varied from 0.81 to 3.52 folds and the level of lipase varied from 1.84 to 12.99 in folliculitis strains. The phospholipase highest expression level was 12.4 folds shown in S3 isolate collected from folliculitis (Table 5). Upregulation was noted in strains collected from control group for lipase in only 1 isolate and for keratinase and phospholipase in 2 isolates. A statistical significant difference of the lipase gene expression $(P=0.072)$ was associated with the strains collected from patient with folliculitis vs group control. The overproduction of the 3 genes was observed in a 5 strains (S2, S3, S7, S10 and S13). The overexpression of the keratinase, lipase and phospholipase genes was associated with an increased copy number of gene in 8 strains of $M$. globosa (Table 5).

In addition, correlation analysis results with Pearson's coefficient revealed that there was statistically significant positive association between the production of the enzymes and the expression of their genes: keratinase $(r=0.881, P<0.0001)$, lipase $(r=0.530, P=0.016)$ and phospholipase $(r=0.754$, $P=0.0001)$.

\section{Discussion}

In the present study we examined multiple virulence factors such as extracellular secreted hydrolytic enzymes and biofilm development which contribute to the ability of Malassezia species to colonize host tissues, and cause disease. However, a few number of studies focused on virulence factors' expression and pathogenesis of the Malassezia species.

Our results demonstrated that all Malassezia species included in our study, like many other fungal and bacterial species [15] produced biofilms through a discrete sequence of events, including fungal surface adhesion, microcolony formation, and biofilm maturation.

A better knowledge of the mechanisms of antifungal drug resistance may lead to the development of novel therapies for biofilm-based diseases. Multiple mechanisms have been proposed for the biofilm resistance phenomenon [16]. Metabolic quiescence has been proposed as a mechanism of antimicrobial resistance in biofilm bacteria [17] and fungi [16]. However, our data revealed that CVS activity showed biofilm cells to be metabolically active in our Malassezia species, in line with data previously reported for Candida albicans and C. parapsilosis [18]. It is therefore unlikely that biofilm production is a major factor promoting antifungal resistance of Malassezia species [16]. 
Biofilm production was studied only for $M$. furfur $[19,20]$ and $M$. pachydermatis [21]. Angiolella et al, demonstrated that biofilm adherence and hydrophobicity are considered as virulence factors in Malassezia furfur species [20].

Also, these studies showed that M. pachydermatis strains from dogs with or without skin lesions are capable to form biofilm with variable quantity and structures which are likely to be strain-dependent [21].

In our study, we showed that all Malassezia species produced lipase and $95 \%$ of $M$. globosa showed a very high enzymatic activity. In fact, lipases catalyze the hydrolysis of ester bonds of triacylglycerols, resulting in the release of fatty acids. In almost all organisms, lipases play essential roles in lipid metabolism, including digestion, transport, and the processing of dietary lipids. Lipases also play important roles in the virulence of skin-associated lipophilic fungal pathogens of the Malassezia spp. The gene that encodes for lipases in M. furfur, M. pachydermatis, and M. globosa has been identified, and recent genome sequencing efforts have revealed at least 14 lipase-encoding genes in M. globosa [21].

Weerapong et al suggested that lipase may be a pathogenic factor in the skin disease associated with Malassezia and provide an explanation to why $M$. globosa is an important pathogenic species in several human skin diseases despite its slow rate of growth [12].

Interestingly, we showed a high lipase activity from $M$. globosa strains isolated from pityriasis versicolor. In previous study, M. globosa, one of the most frequently isolated Malassezia spp. from patients with dandruff and seborrheic dermatitis, displayed extracellular lipase activity [9, 22, 23].

Phospholipase activity is another virulence factor exhibited by pathogenic microorganisms which permits to hydrolyze one or more ester linkages in glycerophospholipids, resulting in the release of free fatty acids.

In this study, all strains had the ability to express phospholipase expect for $M$. restricta with only $70 \%$ were phospholipase producers. Additionally, we noted a high phospholipase activity for Malassezia isolates recovered from Neonates group samples.

This virulence factor intrinsic to Malassezia yeasts has been discussed in association with the pathogenesis of seborrheic dermatitis. The increased level of production of phospholipase has been shown only for pathogenic M. pachydermatis strains [10].

Current information on phospholipases in Malassezia spp. is limited. Juntachai et al. detected extracellular phospholipase activities in $M$. furfur, $M$. pachydermatis, M. slooffiae, M. sympodialis, M. globosa, M. restricta, and M. obtusa. However, enzyme activity was higher only in M. pachydermatis [24].

The ability to express enzymes not only varies among different species of Malassezia but also differs among the strains of same species isolated from different clinical manifestations. Interestingly, we showed that strains isolated from different groups patients produced phospholipase. The production of Malassezia phospholipases on the skin could result in the removal of epidermal lipids, disruption of the epidermal barrier function, and the development of seborrheic dermatitis when sebum production is constitutionally decreased [10].

The keratinases are proteolytic enzymes in nature. They mainly attack the disulfide bond of the keratin substrate $[25,26]$.

As previously reported the dermatophytes and non-dermatophytes species were both keratinase producers and they are capable of damaging the keratinized structure of the skin [26-28]. In our study, all $M$. slooffiae isolates were keratinase producers. However, only the half of $M$. furfurhas a positive enzymatic activity. Peyton et al found that $M$. furfur is capable of degrading keratin $[26,29]$. But, Muhsin et al reported negative keratinase activity in $M$. furfur [26].

In our study we found a positive correlation between the secretion of keratinase and phospholipase. These virulence factors appear to act synergistically to contribute to the virulence of Malassezia strains.

The genome sequencing data revealed that $M$. globosa possesses a total of 14 lipases and 9 phospholipases. Among them, four lipases (MGL_3878, MGL_3507 MGL_0799, and MGL_0798) and two phospholipases (MGL_4252 and MGL_3326) were expressed on human scalps [30]. Few studies were carried out to analyze expression of lipases and phospholipases of the fungus [31]. However, to our knowledge no information is currently available for expression of keratinase. In our study, the RT-qPCR analysis of expression and copy number of the 3 genes responsible for the virulence of $20 \mathrm{M}$. globosa, showed the overexpression of one or more genes in $5 / 5$ of folliculitis strains and $7 / 8$ in pityriasis versicolor isolates. The phospholipase highest expression level was 12.4 folds shown in isolates collected from folliculitis. Moreover, we noted a statistical significant difference of the lipase gene expression $(P=0.072)$ was associated with the strains collected from patient with folliculitis vs group control. These data imply a possible role of lipase in the host environment to produce free fatty acids for the fungus. The concurrently overproduction of the three genes was observed in a five strains isolated from patients with folliculitis and pityriasis versicolor. However, overexpression was noted in only 2 cases of control group suggesting that theses enzymes play an important role in the pathogenicity of Malassezia disorder inducing a transition from colonization to infection. Interestingly, further studies evaluated the expression of lipases and phospholipases of Malassezia restricta in patients with seborrheic dermatitis and suggested that majority of the patients displayed expression of these enzymes [32].

Moreover, Patino-Uzcategui et al. found a significant higher expression of MGL 0797, MGL 0798, and Mflip1 virulence genes in Seborrheic Dermatitis HIV patients. They concluded that lipases may be related to the development of Seborrheic Dermatitis and could be considered as virulence factors [8].

In the study of Gharehbolagh et al, the Real-time PCR was applied to investigate the contribution of the MGL_3741 gene to pathogenicity of Malassezia globosa in pityriasis versicolor. These authors revealed that this gene can be related to the pathogenicity of this yeast and it can be a candidate for new antifungal investigation with better action to treatment of pityriasis versicolor [33]. However, further studies are steel needed to determine this role. 


\section{Conclusion}

This investigation provides more information about the frequency of the production of the major enzymes considered to be virulence factors of Malassezia species. Interestingly, the overexpression of one or more genes was observed in strains isolated from patients with Malassezia disorder. These data emphasizes the role of lipase and phospholipase in the pathogenicity of this fungus and suggest that theses enzymes act synergically for inducing Malassezia pathologies.

\section{Declarations}

\section{Acknowledgments}

This research was funded by the ministry of higher education and scientific research, Tunisia.

Disclosure of potential conflicts of interest: The authors report no conflicts of interest. The authors alone are responsible for the content and writing of the paper.

Funding: NA

\section{Informed consent: NA}

\section{References}

1. Pedrosa, A.F., Lisboa, C., and Goncalves Rodrigues, A. (2014). Malassezia infections: a medical conundrum. J Am Acad Dermatol 71, 170-176.

2. Ashbee, H.R. (2007). Update on the genus Malassezia. Med Mycol 45, 287-303.

3. Bond, R. (2010). Superficial veterinary mycoses. Clin Dermatol 28, 226-236.

4. Gaitanis, G., Magiatis, P., Hantschke, M., Bassukas, I.D., and Velegraki, A. (2012). The Malassezia genus in skin and systemic diseases. Clin Microbiol Rev 25, 106-141.

5. Nardoni, S., Mancianti, F., Rum, A., and Corazza, M. (2005). Isolation of Malassezia species from healthy cats and cats with otitis. J Feline Med Surg 7, 141-145.

6. Shokri, H., Khosravi, A., Rad, M., and Jamshidi, S. (2010). Occurrence of Malassezia species in Persian and domestic short hair cats with and without otitis externa. J Vet Med Sci 72, 293-296.

7. Kaneko, T., Murotani, M., Ohkusu, K., Sugita, T., and Makimura, K. (2012). Genetic and biological features of catheter-associated Malassezia furfur from hospitalized adults. Med Mycol 50, 74-80.

8. Patino-Uzcategui, A., Amado, Y., Cepero de Garcia, M., Chaves, D., Tabima, J., Motta, A., Cardenas, M., Bernal, A., Restrepo, S., and Celis, A. (2011). Virulence gene expression in Malassezia spp from individuals with seborrheic dermatitis. J Invest Dermatol 131, 2134-2136.

9. Vlachos, C., Gaitanis, G., Alexopoulos, E.C., Papadopoulou, C., and Bassukas, I.D. (2013). Phospholipase activity after beta-endorphin exposure discriminates Malassezia strains isolated from healthy and seborrhoeic dermatitis skin. J Eur Acad Dermatol Venereol 27, 1575-1578.

10. Cannizzo, F.T., Eraso, E., Ezkurra, P.A., Villar-Vidal, M., Bollo, E., Castella, G., Cabanes, F.J., Vidotto, V., and Quindos, G. (2007). Biofilm development by clinical isolates of Malassezia pachydermatis. Med Mycol 45, 357-361.

11. Ilahi, A., Hadrich, I., Neji, S., Trabelsi, H., Makni, F., and Ayadi, A. (2017). Real-Time PCR Identification of Six Malassezia Species. Curr Microbiol 74, 671677.

12. Jin, Y., Yip, H.K., Samaranayake, Y.H., Yau, J.Y., and Samaranayake, L.P. (2003). Biofilm-forming ability of Candida albicans is unlikely to contribute to high levels of oral yeast carriage in cases of human immunodeficiency virus infection. J Clin Microbiol 41, 2961-2967.

13. Machado, M.L., Cafarchia, C., Otranto, D., Ferreira, R.R., Bianchi, S.P., Latrofa, M.S., Parisi, A., and Ferreiro, L. (2010). Genetic variability and phospholipase production of Malassezia pachydermatis isolated from dogs with diverse grades of skin lesions. Med Mycol 48, 889-892.

14. Coutinho, S.D., and Paula, C.R. (2000). Proteinase, phospholipase, hyaluronidase and chondroitin-sulphatase production by Malassezia pachydermatis. Med Mycol 38, 73-76.

15. Davey, M.E., and O'Toole G, A. (2000). Microbial biofilms: from ecology to molecular genetics. Microbiol Mol Biol Rev 64, $847-867$.

16. Mukherjee, P.K., and Chandra, J. (2004). Candida biofilm resistance. Drug Resist Updat 7, 301-309.

17. Mah, T.F., and O'Toole, G.A. (2001). Mechanisms of biofilm resistance to antimicrobial agents. Trends Microbiol 9, 34-39.

18. Kuhn, D.M., Chandra, J., Mukherjee, P.K., and Ghannoum, M.A. (2002). Comparison of biofilms formed by Candida albicans and Candida parapsilosis on bioprosthetic surfaces. Infect Immun 70, 878-888.

19. Simonetti, G., Tocci, N., Valletta, A., Brasili, E., D'Auria, F.D., Idoux, A., and Pasqua, G. (2016). In vitro antifungal activity of extracts obtained from Hypericum perforatum adventitious roots cultured in a mist bioreactor against planktonic cells and biofilm of Malassezia furfur. Nat Prod Res 30, 544550.

20. Angiolella, L., Leone, C., Rojas, F., Mussin, J., de Los Angeles Sosa, M., and Giusiano, G. (2018). Biofilm, adherence, and hydrophobicity as virulence factors in Malassezia furfur. Med Mycol 56, 110-116.

21. Figueredo, L.A., Cafarchia, C., Desantis, S., and Otranto, D. (2012). Biofilm formation of Malassezia pachydermatis from dogs. Vet Microbiol 160, $126-131$. 
22. Plotkin, L.I., Squiquera, L., Mathov, I., Galimberti, R., and Leoni, J. (1996). Characterization of the lipase activity of Malassezia furfur. J Med Vet Mycol 34, 43-48.

23. DeAngelis, Y.M., Saunders, C.W., Johnstone, K.R., Reeder, N.L., Coleman, C.G., Kaczvinsky, J.R., Jr., Gale, C., Walter, R., Mekel, M., Lacey, M.P., et al. (2007). Isolation and expression of a Malassezia globosa lipase gene, LIP1. J Invest Dermatol 127, 2138-2146.

24. Juntachai, W., Oura, T., Murayama, S.Y., and Kajiwara, S. (2009). The lipolytic enzymes activities of Malassezia species. Med Mycol 47, $477-484$.

25. Bockle, B., Galunsky, B., and Muller, R. (1995). Characterization of a keratinolytic serine proteinase from Streptomyces pactum DSM 40530. Appl Environ Microbiol 61,3705-3710.

26. Gupta, R., and Ramnani, P. (2006). Microbial keratinases and their prospective applications: an overview. Appl Microbiol Biotechnol 70, 21-33.

27. Takiuchi, I., Sei, Y., Takagi, H., and Negi, M. (1984). Partial characterization of the extracellular keratinase from Microsporum canis. Sabouraudia 22, 219224.

28. Yu, R.J., Harmon, S.R., Grappel, S.F., and Blank, F. (1971). Two cell-bound keratinases of Trichophyton mentagrophytes. J Invest Dermatol 56, $27-32$.

29. Peyton, C.C., Keys, T., Tomblyn, S., Burmeister, D., Beumer, J.H., Holleran, J.L., Sirintrapun, J., Washburn, S., and Hodges, S.J. (2012). Halofuginone infused keratin hydrogel attenuates adhesions in a rodent cecal abrasion model. J Surg Res 178, 545-552.

30. Xu, J., Saunders, C.W., Hu, P., Grant, R.A., Boekhout, T., Kuramae, E.E., Kronstad, J.W., Deangelis, Y.M., Reeder, N.L., Johnstone, K.R., et al. (2007). Dandruffassociated Malassezia genomes reveal convergent and divergent virulence traits shared with plant and human fungal pathogens. Proc Natl Acad Sci U S A $104,18730-18735$.

31. Brunke, S., and Hube, B. (2006). MfLIP1, a gene encoding an extracellular lipase of the lipid-dependent fungus Malassezia furfur. Microbiology 152, 547554.

32. Lee, Y.W., Lee, S.Y., Lee, Y., and Jung, W.H. (2013). Evaluation of Expression of Lipases and Phospholipases of Malassezia restricta in Patients with Seborrheic Dermatitis. Ann Dermatol 25, 310-314.

33. Aghaei Gharehbolagh, S., Kordbacheh, P., Hashemi, S.J., Daie Ghazvini, R., Asgari, Y., Agha Kuchak Afshari, S., Seyedmousavi, S., and Rezaie, S. (2018). MGL_3741 gene contributes to pathogenicity of Malassezia globosa in pityriasis versicolor. Mycoses 61, 938-944.

\section{Tables}

Table 1. The sequences of primers and probes used in RT-qPCR for gene expression of $20 \mathrm{M}$. globosa isolates

\begin{tabular}{lll} 
Enzymes & Names & Sequences \\
\hline Keratinase & KerF & 5'-ACGTCATGCTCAGATTGCAG-3' \\
\cline { 2 - 3 } & KerR & 5'-GACTTCCGCGAAGAACAAAG-3' \\
\cline { 2 - 3 } Lipase & KerP & 5'-FAM-CACAATTGCTCCCGATACCT-MGB \\
\cline { 2 - 3 } & LipF & 5'-ACCCAACATTTGCTTCGTTC-3' \\
\hline Phospholipase & LipR & 5'-TCAATTATCAATGGTCGCGA-3' \\
\cline { 2 - 3 } & LipP & 5'-FAM-CCTTGGTGGTCGTCAAAGTT-MGB \\
\cline { 2 - 3 } & 5hosR & 5'-AACTGGTGGATTTGCTGACC-3' \\
\hline Actin & PhosP & 5'-FAM-CCGTGTGCCATTCTACATTG-MGB \\
\hline & ActF & 5'-CTCTCCTTGTACGCCTCTGG-3' \\
\cline { 2 - 3 } & ActR & 5'-TTGACAAGATGCTCCGTCAG-3' \\
\cline { 2 - 3 } & ActP & 5'-TET-GTATTGTGCTGGACTCGGGT-MGB \\
& &
\end{tabular}

Table 2. Biofilm production for Malassezia species isolated from different clinical sites 


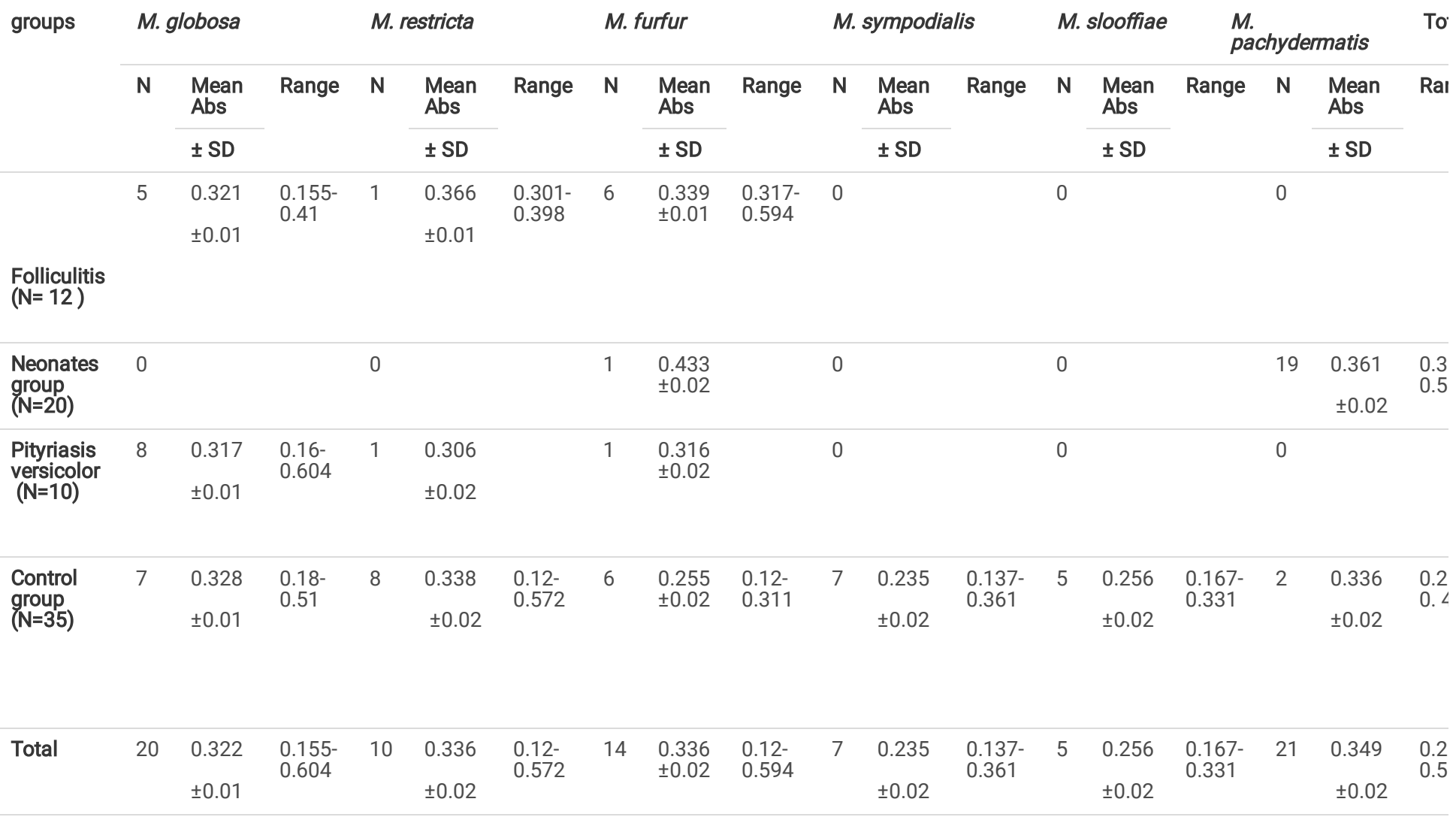

$\mathrm{N}$ : number of tested isolates

SD: standard deviation

Table 3. Level of phospholipase, lipase and keratinase production by Malassezia species.

$\mathrm{N}$ : number of tested isolates

$\mathrm{n}$ : number of isolates with positive activity for the corresponding hydrolytic enzyme

SD: standard deviation

Table 4. Distribution of enzymatic activities of Malassezia species isolated from different clinical sites 


\begin{tabular}{|c|c|c|c|c|c|c|c|c|c|c|c|}
\hline & \multicolumn{4}{|c|}{$\begin{array}{l}\text { Phospholipase activity } \\
\text { number of isolates (rate of isolates) }\end{array}$} & \multicolumn{3}{|c|}{$\begin{array}{l}\text { Lipase activity } \\
\text { number of isolates (rate of } \\
\text { isolates) }\end{array}$} & \multicolumn{4}{|c|}{$\begin{array}{l}\text { Keratinase activity } \\
\text { number of isolates (rate of isolates) }\end{array}$} \\
\hline & $\begin{array}{l}\text { Mean } \\
(P Z) \\
\pm \text { SD }\end{array}$ & $\begin{array}{l}\text { very high n } \\
\text { (\%) }\end{array}$ & $\begin{array}{l}\text { high } \\
\text { n (\%) }\end{array}$ & $\begin{array}{l}\text { Nul } \\
\text { (\%) }\end{array}$ & $\begin{array}{l}\text { Mean } \\
(P \mathrm{Z}) \\
\pm \mathrm{SD}\end{array}$ & $\begin{array}{l}\text { very high n } \\
\text { (\%) }\end{array}$ & $\begin{array}{l}\text { high } \\
\text { n (\%) }\end{array}$ & $\begin{array}{l}\text { Mean } \\
(P z) \\
\pm \text { SD }\end{array}$ & $\begin{array}{l}\text { very } \\
\text { high }\end{array}$ & $\begin{array}{l}\text { high } \\
\text { n (\%) }\end{array}$ & nul \\
\hline $\begin{array}{l}\text { Malassezia globosa } \\
(\mathrm{N}=20)\end{array}$ & $\begin{array}{l}0.64 \\
\pm 0.03\end{array}$ & $\begin{array}{l}9 \\
(45)\end{array}$ & $\begin{array}{l}11 \\
(55)\end{array}$ & $\begin{array}{l}0 \\
(0)\end{array}$ & $\begin{array}{l}0.55 \\
\pm 0.02\end{array}$ & $\begin{array}{l}19 \\
(95)\end{array}$ & $\begin{array}{l}1 \\
(5)\end{array}$ & $\begin{array}{l}0.65 \\
\pm 0.02\end{array}$ & $\begin{array}{l}10 \\
(50)\end{array}$ & $\begin{array}{l}6 \\
(30)\end{array}$ & $\begin{array}{l}4 \\
(20)\end{array}$ \\
\hline $\begin{array}{l}\text { Malassezia restricta } \\
(\mathrm{N}=10)\end{array}$ & $\begin{array}{l}0.76 \\
\pm 0.02\end{array}$ & $\begin{array}{l}0 \\
(0)\end{array}$ & $\begin{array}{l}7 \\
(70)\end{array}$ & $\begin{array}{l}3 \\
(30)\end{array}$ & $\begin{array}{l}0.36 \\
\pm 0.03\end{array}$ & $\begin{array}{l}10 \\
(100)\end{array}$ & $\begin{array}{l}0 \\
(0)\end{array}$ & $\begin{array}{l}0.69 \\
\pm 0.02\end{array}$ & $\begin{array}{l}0 \\
(0)\end{array}$ & $\begin{array}{l}2 \\
(20)\end{array}$ & $\begin{array}{l}8 \\
(80)\end{array}$ \\
\hline $\begin{array}{l}\text { Malassezia furfur } \\
(\mathrm{N}=14)\end{array}$ & $\begin{array}{l}0.64 \\
\pm 0.02\end{array}$ & $\begin{array}{l}2 \\
(14.29)\end{array}$ & $\begin{array}{l}12 \\
(85.71)\end{array}$ & $\begin{array}{l}0 \\
(0)\end{array}$ & $\begin{array}{l}0.45 \\
\pm 0.03\end{array}$ & $\begin{array}{l}14 \\
(100)\end{array}$ & $\begin{array}{l}0 \\
(0)\end{array}$ & $\begin{array}{l}0.67 \\
\pm 0.02\end{array}$ & $\begin{array}{l}1 \\
(7.15)\end{array}$ & $\begin{array}{l}6 \\
(42.85)\end{array}$ & $\begin{array}{l}7 \\
(50)\end{array}$ \\
\hline $\begin{array}{l}\text { Malassezia } \\
\text { sympodialis } \\
(\mathrm{N}=7)\end{array}$ & $\begin{array}{l}0.67 \\
\pm 0.02\end{array}$ & $\begin{array}{l}1 \\
(14.29)\end{array}$ & $\begin{array}{l}6 \\
(85.71)\end{array}$ & $\begin{array}{l}0 \\
(0)\end{array}$ & $\begin{array}{l}0.54 \\
\pm 0.02\end{array}$ & $\begin{array}{l}5 \\
(71.43)\end{array}$ & $\begin{array}{l}2 \\
(28.57)\end{array}$ & $\begin{array}{l}0.62 \\
\pm 0.03\end{array}$ & $\begin{array}{l}1 \\
(14.3)\end{array}$ & $\begin{array}{l}3 \\
(42.85)\end{array}$ & $\begin{array}{l}3 \\
(42.85)\end{array}$ \\
\hline $\begin{array}{l}\text { Malassezia slooffiae } \\
(\mathrm{N}=5)\end{array}$ & $\begin{array}{l}0.64 \\
\pm 0.02\end{array}$ & $\begin{array}{l}2 \\
(40)\end{array}$ & $\begin{array}{l}3 \\
(60)\end{array}$ & $\begin{array}{l}0 \\
(0)\end{array}$ & $\begin{array}{l}0.4 \\
\pm 0.04\end{array}$ & $\begin{array}{l}5 \\
(100)\end{array}$ & $\begin{array}{l}0 \\
(0)\end{array}$ & $\begin{array}{l}0.67 \\
\pm 0.02\end{array}$ & $\begin{array}{l}2 \\
(40)\end{array}$ & $\begin{array}{l}3 \\
(60)\end{array}$ & $\begin{array}{l}0 \\
(0)\end{array}$ \\
\hline $\begin{array}{l}\text { Malassezia } \\
\text { pachydermatis } \\
(\mathrm{N}=21)\end{array}$ & $\begin{array}{l}0.64 \\
\pm 0.03\end{array}$ & $\begin{array}{l}9 \\
(42.86)\end{array}$ & $\begin{array}{l}12 \\
(57.14)\end{array}$ & $\begin{array}{l}0 \\
(0)\end{array}$ & $\begin{array}{l}0.31 \\
\pm 0.02\end{array}$ & $\begin{array}{l}21 \\
(100)\end{array}$ & $\begin{array}{l}0 \\
(0)\end{array}$ & $\begin{array}{l}0.68 \\
\pm 0.02\end{array}$ & $\begin{array}{l}3 \\
(14.29)\end{array}$ & $\begin{array}{l}8 \\
(38.5)\end{array}$ & $\begin{array}{l}10 \\
(47.66)\end{array}$ \\
\hline Total & $\begin{array}{l}0.66 \\
\pm 0.02\end{array}$ & $\begin{array}{l}23 \\
(29.87)\end{array}$ & $\begin{array}{l}51 \\
(66.23)\end{array}$ & $\begin{array}{l}3 \\
(3.9)\end{array}$ & $\begin{array}{l}0.48 \\
\pm 0.02\end{array}$ & $\begin{array}{l}74 \\
(91.1)\end{array}$ & $\begin{array}{l}3 \\
(3.9)\end{array}$ & $\begin{array}{l}0.66 \\
\pm 0.02\end{array}$ & $\begin{array}{l}17 \\
(22.08)\end{array}$ & $\begin{array}{l}28 \\
(36.36)\end{array}$ & $\begin{array}{l}32 \\
(41.56)\end{array}$ \\
\hline
\end{tabular}




\begin{tabular}{|c|c|c|c|c|c|}
\hline & M. globosa (20) & $0.69 \pm 0.01$ & - & $0.74 \pm 0.02$ & $0.73 \pm 0.02$ \\
\hline Phospholipase activity & & $(5 / 12)$ & $(0 / 20)$ & $(8 / 10)$ & $(7 / 35)$ \\
\hline \multirow[t]{12}{*}{ Mean $(P \mathrm{Z}) \pm \mathrm{SD}$} & M. restricta (10) & $0.67 \pm 0.01$ & - & $0.8 \pm 0.02$ & $0.83 \pm 0.02$ \\
\hline & & $(1 / 12)$ & $(0 / 20)$ & $(1 / 10)$ & $(8 / 35)$ \\
\hline & M. furfur (14) & $0.74 \pm 0.01$ & $0.70 \pm 0.02$ & $0.69 \pm 0.02$ & $0.71 \pm 0.01$ \\
\hline & & $(6 / 12)$ & $(1 / 20)$ & $(1 / 10)$ & $(6 / 35)$ \\
\hline & M. sympodialis (7) & - & - & - & $0.78 \pm 0.02$ \\
\hline & & $(0 / 12)$ & $(0 / 20)$ & $(0 / 10)$ & $(7 / 35)$ \\
\hline & M. slooffiae (5) & 0 & - & - & $0.77 \pm 0.02$ \\
\hline & & $(0 / 12)$ & $(0 / 20)$ & $(0 / 10)$ & $(5 / 35)$ \\
\hline & M. pachydermatis (21) & 0 & $0.66 \pm 0.02$ & - & $0.79 \pm 0.01$ \\
\hline & & $(0 / 12)$ & $(19 / 20)$ & $(0 / 10)$ & $(2 / 35)$ \\
\hline & Total & $0.70 \pm 0.01$ & $0.68 \pm 0.02$ & $0.74 \pm 0.02$ & $0.77 \pm 0.02$ \\
\hline & M. globosa (20) & $0.36 \pm 0.01$ & - & $0.36 \pm 0.02$ & $0.38 \pm 0.02$ \\
\hline \multirow[t]{2}{*}{ Lipase activity } & & $(5 / 12)$ & $(0 / 20)$ & $(8 / 10)$ & $(7 / 35)$ \\
\hline & M. restricta (10) & $0.37 \pm 0.01$ & - & $0.32 \pm 0.02$ & $0.36 \pm 0.02$ \\
\hline \multirow[t]{13}{*}{$\operatorname{Mean}(P Z) \pm S D$} & & $(1 / 12)$ & $(0 / 20)$ & $(1 / 10)$ & $(8 / 35)$ \\
\hline & M. furfur (14) & $0.32 \pm 0.02$ & $0.39 \pm 0.02$ & $0.28 \pm 0.01$ & $0.36 \pm 0.02$ \\
\hline & & $(6 / 12)$ & $(1 / 20)$ & $(1 / 10)$ & $(6 / 35)$ \\
\hline & M. sympodialis (7) & - & - & - & $0.48 \pm 0.02$ \\
\hline & & $(0 / 12)$ & $(0 / 20)$ & $(0 / 10)$ & $(7 / 35)$ \\
\hline & M. slooffiae (5) & - & - & - & $0.4 \pm 0.01$ \\
\hline & & $(0 / 12)$ & $(0 / 20)$ & $(0 / 10)$ & $(5 / 35)$ \\
\hline & M. pachydermatis (21) & - & $0.31 \pm 0.01$ & - & $0.38 \pm 0.02$ \\
\hline & & $(0 / 12)$ & $(19 / 20)$ & $(0 / 10)$ & $(2 / 35)$ \\
\hline & Total & $0.35 \pm 0.02$ & $0.35 \pm 0.02$ & $0.32 \pm 0.02$ & $0.39 \pm 0.02$ \\
\hline & M. globosa (20) & $0.75 \pm 0.02$ & - & $0.62 \pm 0.02$ & $0.85 \pm 0.02$ \\
\hline & & $(5 / 12)$ & $(0 / 20)$ & $(8 / 10)$ & $(7 / 35)$ \\
\hline & M. restricta (10) & 1 & - & $0.65 \pm 0.02$ & 1 \\
\hline \multirow[t]{2}{*}{ Keratinase activity } & & $(1 / 12)$ & $(0 / 20)$ & $(1 / 10)$ & $(8 / 35)$ \\
\hline & M. furfur (14) & $0.82 \pm 0.02$ & $0.53 \pm 0.02$ & $0.65 \pm 0.02$ & $0.96 \pm 0.02$ \\
\hline \multirow[t]{8}{*}{$\operatorname{Mean}(P \mathrm{z}) \pm \mathrm{SD}$} & & $(6 / 12)$ & $(1 / 20)$ & $(1 / 10)$ & $(6 / 35)$ \\
\hline & M. sympodialis (7) & - & - & - & $0.84 \pm 0.02$ \\
\hline & & $(0 / 12)$ & $(0 / 20)$ & $(0 / 10)$ & $(7 / 35)$ \\
\hline & M. slooffiae (5) & - & - & - & $0.8 \pm 0.02$ \\
\hline & & $(0 / 12)$ & $(0 / 20)$ & $(0 / 10)$ & $(5 / 35)$ \\
\hline & M. pachydermatis (21) & - & $0.85 \pm 0.02$ & - & $0.79 \pm 0.02$ \\
\hline & & $(0 / 12)$ & $(19 / 20)$ & $(0 / 10)$ & $(2 / 35)$ \\
\hline & Total & $0.86 \pm 0.02$ & $0.69 \pm 0.02$ & $0.64 \pm 0.02$ & $0.873 \pm 0.02$ \\
\hline
\end{tabular}

SD: standard deviation 
Table 5. Relative quantification of gene expression and gene copy number of keratinase, lipase and phospholipase genes in 20 M. globosa strains

\begin{tabular}{|c|c|c|c|c|c|c|c|}
\hline \multirow[t]{2}{*}{ ID } & \multirow[t]{2}{*}{ clinical sites } & \multicolumn{3}{|c|}{ RNA relative quantification } & \multicolumn{3}{|c|}{ DNA relative quantification } \\
\hline & & Keratinase & Lipase & Phospholipase & Keratinase & Lipase & Phospholipase \\
\hline S1 & Folliculitis & 2.11 & 1.84 & 2.59 & 4.43 & 7.22 & 3.06 \\
\hline S2 & Folliculitis & 2.52 & 7.51 & 7.57 & 1.36 & 2.04 & 1.08 \\
\hline S3 & Folliculitis & 3.52 & 12.99 & 12.40 & 1.50 & 2.12 & 3.36 \\
\hline S4 & Folliculitis & 0.81 & 3.20 & 3.91 & 0.32 & 12.98 & 0.69 \\
\hline S5 & Folliculitis & 3.40 & 5.55 & 1.48 & 6.58 & 9.57 & 6.36 \\
\hline S6 & Pityriasis versicolor & 0.49 & 0.31 & 0.78 & 0.29 & 0.21 & 0.02 \\
\hline S7 & Pityriasis versicolor & 2.65 & 3.52 & 3.17 & 1.35 & 1.46 & 1.10 \\
\hline S8 & Pityriasis versicolor & 2.82 & 2.35 & 2.54 & 2.79 & 7.43 & 1.34 \\
\hline S9 & Pityriasis versicolor & 1.25 & 3.10 & 2.53 & 0.77 & 1.60 & 0.24 \\
\hline S10 & Pityriasis versicolor & 2.57 & 2.55 & 2.52 & 1.96 & 1.56 & 3.33 \\
\hline S11 & Pityriasis versicolor & 2.84 & 2.75 & 1.32 & 0.97 & 1.74 & 1.03 \\
\hline S12 & Pityriasis versicolor & 0.96 & 2.86 & 3.37 & 0.46 & 0.86 & 2.56 \\
\hline S13 & Pityriasis versicolor & 2.55 & 2.86 & 3.38 & 1.50 & 2.58 & 1.88 \\
\hline S14 & Control group & 1.53 & 0.53 & 0.56 & 1.42 & 0.82 & 0.75 \\
\hline S15 & Control group & 1.04 & 1.19 & 2.55 & 0.92 & 1.05 & 0.86 \\
\hline S16 & Control group & 0.67 & 1.36 & 0.48 & 0.50 & 0.61 & 0.32 \\
\hline S17 & Control group & 0.94 & 2.37 & 2.43 & 0.50 & 1.06 & 2.33 \\
\hline S18 & Control group & 2.36 & 0.07 & 0.48 & 1.87 & 0.26 & 0.49 \\
\hline S19 & Control group & 0.24 & 2.52 & 2.80 & 0.56 & 1.31 & 1.39 \\
\hline S20 & Control group & 2.51 & 3.30 & 1.50 & 1.31 & 1.18 & 0.27 \\
\hline
\end{tabular}

\section{Figures}

\section{Biofilm production}

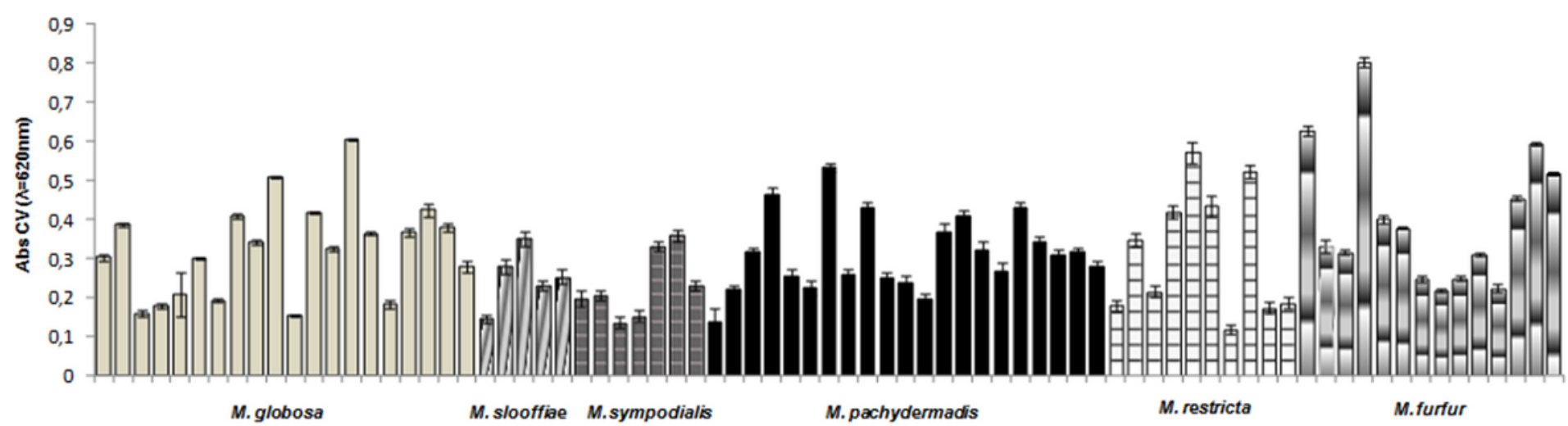

Figure 1

Absorbance values of biofilm quantification using Crystal Violet staining (Abs CV) of different Malassezia species $(\lambda=620 \mathrm{~nm})$. Error bars represent standard deviation. 